\title{
Formation Of The Organizational Model For The Implementation Of Low-Rise Housing Investment Project And Evaluation Of Interaction Effectiveness Of Its Actors
}

\author{
Nikolay N. Minaev \\ Department of Economics of Natural Resources \\ National Research Tomsk Polytechnic University \\ Tomsk, Russia \\ E-mail: nnminaev@mail.ru
}

Irina V. Sharf

Department of Economics of Natural Resources National Research Tomsk Polytechnic University Tomsk, Russia

E-mail: irina_sharf@mail.ru

\section{Christina E. Filyushina}

Department of Economics and Urban Management, Tomsk State University of Civil Engineering Tomsk, Russia

E-mail: kri1617@yandex.ru

\section{Natalia V. Gusakova}

Department of Economics and Urban Management, Tomsk State University of Civil Engineering Tomsk, Russia

E-mail: gusakovanata@mail.ru

\author{
Olga I. Dobrynina \\ Department of Economics and Urban Management, \\ Tomsk State University of Civil Engineering \\ Tomsk, Russia \\ E-mail: dobrynina oly@mail.ru
}

\section{Ekaterina A. Zharova}

Department of Economics and Urban Management, Tomsk State University of Civil Engineering

Tomsk, Russia

E-mail: lightmoon2015@ mail.ru

\section{Julia A. Merkulieva}

Department of Economics and Urban Management, Tomsk State University of Civil Engineering

Tomsk, Russia

E-mail: uliy94j@mail.ru

\author{
Natalya V. Dmitrieva \\ Department of Geology and Geophysics \\ Novosibirsk State University \\ Novosibirsk, Russia \\ E-mail:dmnv@igm.nsc.ru
}

\begin{abstract}
Subject. The paper studied the regularities of the formation of interactions between participants of the investment project of low-rise housing construction in Russia and developed the method of effectiveness assessment. Goal. The development of basic organizational model of interaction in the implementation of investment projects of low-rise housing construction in Russia. Methods. In this paper, with the help of statistical methods we analyzed investment projects of low-rise housing construction, simulation methods contributed to developing the basic model of interaction of subjects of investment project, using econometric methods we identified basic functions of the considered actors and identified the main risks arising in the course of the project, as well as methods of indicative planning helped to develop a new scheme of interaction between the participants of the investment project of low-rise residential buildings and
\end{abstract}

This work was performed within the framework of the Russian President's grant number MK-5341.2016.6 "Formation of the conceptual regional model of management intensification of the implementation of public-private partnership projects in low-rise construction to meet the requirements of energy efficiency" effectiveness estimation of their interactions. Application area. These results can be applied in the development of sectoral territorial planning documents, as well as in programs for the construction industry development, including low-rise housing. Results. The patterns, the problems of interactions between investment project participants are identified and the economic nature of these problems is reveiled. The authors have shown a new basic model of interaction of actors of low-rise housing construction and the method of evaluating the effectiveness of their interaction. Significance. The importance of this article derives from the fact that with the help of the developed model of interaction of the main actors of the low-rise housing qualitative-functional and subjective spheres can be identified in which functions of low-rise housing actors vary depending on a variety of investment techniques. This model shows the interaction between the actors of the investment project and 
the level of responsibility of each of them, as well as the efficiency of interaction between the actors in the implementation of the investment project of low-rise housing construction. Conclusion. On the basis of established patterns and developed system of estimation of interactions effectiveness of actors of low-rise residential construction the authors aim the increase the efficiency of interactions between the actors of the investment project, which in turn provides a more precise planning of low-rise housing projects, as well as reduced financial and economic, political, government, force-major risks, planning risks and innovation risks.

Keywords - low-rise construction, organizational model, risks, indicators, effectiveness estimation.

\section{INTRODUCTION}

Over the past two years, the Russian economy is facing the obvious difficulties of a systemic nature. The investment-building complex proved to be one of the most vulnerable sectors, where the organizational (management), financial, technical and technological (innovative) and other problems are detected, and where they are very closely intertwined. At the same time, the housing problem in Russia today is the most important and urgent, as there is a great need for new housing due to a general per capita shortage, as well as the need to address the issue of citizens' resettlement from shabby (emergency) housing. Thus, currently the number of citizens who are registered as being in need of housing is $2,716,000$, and the number of people who improved their living conditions in 2014 is only 138,000. Thus, the efforts of the Federal target program "Zhilische", which provides assistance in the acquisition of housing for certain categories of citizens are not fully solving the problem. We believe that the obvious reserve may be the development of low-rise construction (LRC), which requires the development of new organizational LRC process control model. In favor of this, we note that the rate of growth of LRC in Russia in recent years has increased significantly, and the share of LRC in general structure of housing construction over the past 5 years has increased from 47.6 to $55 \%$ (Figure 1) and has a tendency to increase. According to the Government of Russian Federation the share of low-rise housing in the total volume of commissioned housing in 2020 should increase to $70 \%$ or up to 142 million square meters, we believe that in terms of financial and economic crisis, this share could rise to $75 \%$ (with some decrease in overall construction). This is caused by the doubtless advantages of LRC over high-rising housing: the mobility of production and technical base, speed and quality of construction, the ability to build a small-sized housing in remote and rural areas (where the cost of land for the construction is lower), higher comfort and safety of living in low-rise buildings, the use of local raw material base, more efficient logistics of construction, the use of autonomous systems of power supply (rejection of more expensive and less reliable centralized sources), less exposure to fluctuations in effective demand, lower cost of construction per unit, lower operating costs, etc. These factors are the basis for the formation of a new organizational model of interactions of key actors of the investment LRC project.

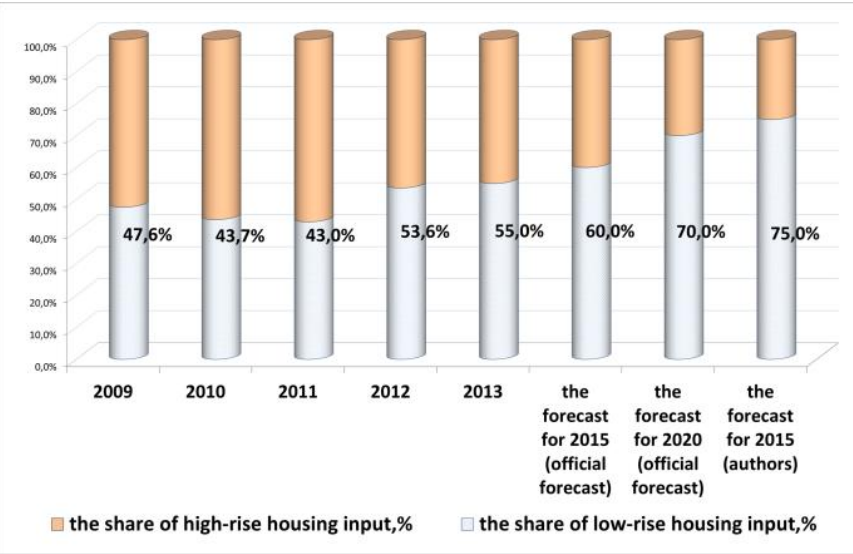

Fig. 1. Structure of housing construction in Russian Federation 2009-2013 (With forecast until 2020), \%.

\section{OVERVIEW OF SCIENTIFIC PUBLICATIONS ON LOW-RISE CONSTRUCTION}

A sufficient number of research works are dedicated to the construction complex development problems, including the development of low-rise housing construction, namely the authors V.S. Kazeikin, S.A. Baronin, A.G. Chernykh, A.N. Androsov in the monograph "Problematic aspects of the development of low-rise housing construction in Russia" considered the main problems of development of low-rise building, not only in Russia, but also abroad, namely wooden housing. The authors analyze the currently existing legal documents and applicable general federal target programs in low-rise construction, and offer guidelines for the formation of the economic mechanism of development of effective regional markets for the low-rise residential construction [1].

This study aimed at identifying the existing problems in low-rise construction, but the problems identified are considered from an economic point of view, still require consideration of technological and organizational aspects of low-rise construction, as well as the organization of investment processes, by improving the quality of the construction of low-rise housing in context of availability, security, and process of construction intensification.

Scientists S.A. Baronin and P.G. Grabov analyzed the features of the modern development of low-rise construction in Russia and show the current priorities of development of low-rise construction, which include: energy efficiency, economy and environmental development of low-rise housing [2].

Problems of development of low-rise housing in Russia can be found in the A.N. Asaul monograph, as well as individual houses and systems design and construction issues [3]. The paper provides the most complete classification of low-rise housing, which in turn requires a 
supplement in respect of the construction of low-rise buildings of blocked and mixed type.

Another study on the development of low-rise construction is presented by the authors Bondarenko E.Y. and Ivanenko L.V., in which the authors conducted the analysis of foreign experience of low-rise housing.

According to the experience of leading foreign countries, low-rise building should be constructed with the use of prefabricated technology, namely, there should be clear standardization of construction technology to organize the mass construction of low-rise buildings, with priority given to the development of wooden housing [4]. A lot has been written in the foreign literature about the investment and construction projects in various sectors of the economy based on the principles of public-private partnership $[5,6,7$, $8,9]$, which in turn can be used in Russian practice of lowrise housing.

Basing on the reviewed publications on the given topic $[10,11,12]$, we can conclude that the issue of the development of low-rise construction is quite topical, and there are various problems that require detailed study not only at the stage of design and construction, but also in addressing issues such as the optimization of technological solutions for low-rise construction, the intensification of the construction process, risk assessment in low-rise construction, the development of energy-efficient low-rise buildings of A class [13], the development of models of interaction between the actors of investment and construction project of low-rise housing construction and organization of investment [14].

Thus, the results of the present study are focused on the development of theoretical ideas about the nature of the technical, economic and practical aspects of LRC development in Russia.

\section{METHODOLOGY}

Basic organizational model of interactions of key actors of the investment project aimed at construction of a blocked-type low-rise houses is shown in Figure 2. Analyzing the introduced basic organizational model of interactions we can distinguish qualitative-functional and subjective spheres of investment projects. All actors of the investment project of low-rise construction acquire different functional characteristics, depending on the type of interaction between them. When implementing low-rise investment project the rights and obligations of all construction process participants in the qualitative and functional sphere tend to be clearly defined. Their functions performed in sequence, are mutually reinforcing. Each entity implementing an investment project aimed at construction of low-rise residential houses of blocked type, acquires different qualities depending on the terms of interaction and modification of the model of interaction, namely, any entity can act as a contractor, and customer, as well as a subcontractor. The central object of management of this model is the construction of low-rise houses of the blocked type. A modification of the model is due to the use of different methods of organization of investment activities (for example, a method based on the principles of public-private partnership) and each modification is our quality-functional and subjective options interactions.

In this regard, the following new models of organization of investment in low-rise construction can be identified, namely:

- Mixed model - based on the principles of publicprivate partnership. The most convenient way is to implement this model in depressed areas where there is no sustainable economic and social development. In these projects, the investor commonly realizes the shortterm projects with short invested funds turnover, this method of investing is called mixed partnership.

- Social model - the construction is carried out in accordance with socially significant state programs and financed from the state budget (social housing for the privileged categories of citizens and the resettlement of old and dilapidated housing, young professionals, young families), i.e. financing is mostly carried out only by the authorities. In terms of socio-economic development this model is used in crisis areas, due to lack of points of growth in such territories, these projects are not in demand by investors, as the population shows no consumer demand due to lack of funds. This method of investing in such a model is called social partnership.

- Market model - the state is not involved in the construction of low-rise housing, all construction is undertaken by the initiative of construction organizations. The customer (population) enters into a contract with a construction company for the construction of a blocked-type low-rise houses, a main task of the state in such a model includes environmental and construction monitoring, compliance with rules and regulations of security during construction.

In terms of socio-economic development the market model is used in developed areas, investors realize the investment projects of low-rise housing construction in the long period of time, in areas where land value over the years grows and method of investing in such a model is a market partnership.

Analyzing new models of investment activity organization, presented by the authors it can be concluded that the choice of a particular model depends on the level of socio-economic development of territories and each model has its own set of methods of the organization's investment in low-rise housing construction. Three ways to invest are presented and each model necessitates the analysis and evaluation of possible risks arising from the implementation of specific low-rise projects. 


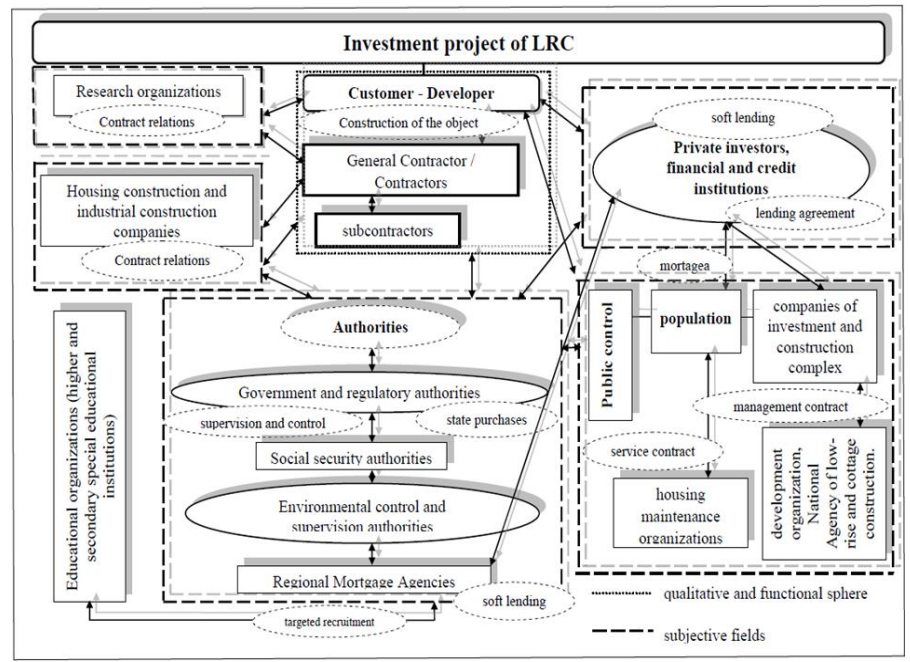

Fig. 2. Basic organizational model of key actors interactions of LRC investment project.

To determine the degree of interaction of each actor in the investment project of low-rise construction authors have developed the basic indicators for the assessment of this impact (Table 1,2).

TABLE I. INDICATORS REFLECTING THE SYSTEM OF INTERACTION BETWEEN THE ACTORS OF LOW-RISE HOUSING CONSTRUCTION INVESTMENT PROJECT.

\begin{tabular}{|c|c|c|c|}
\hline $\begin{array}{c}\text { Indicat } \\
\text { or of } \\
\text { actor } \\
\text { efficien } \\
\text { cy in } \\
\text { LRC } \\
\text { project }\end{array}$ & Indicator description & $\begin{array}{l}\text { Indicator } \\
\text { calculation }\end{array}$ & $\begin{array}{c}\text { Type of } \\
\text { risk } \\
\text { correspo } \\
\text { nding to } \\
\text { the actors } \\
\text { functions }\end{array}$ \\
\hline $\begin{array}{l}\text { Private } \\
\text { investors }\end{array}$ & $\begin{array}{l}\text { Break-even point (T) } \\
\text { calculation determines } \\
\text { what should be the cost } \\
\text { of construction, that } \\
\text { invested funds were } \\
\text { enough to cover all } \\
\text { expenses, excluding } \\
\text { profits, and that the } \\
\text { investment project was } \\
\text { to break even, monetary } \\
\text { units. B - revenue from } \\
\text { sales of the investment } \\
\text { project; VC - variable } \\
\text { costs; FC - fixed costs. }\end{array}$ & $\mathrm{T}=(\mathrm{B} \times \mathrm{FC}) /(\mathrm{B}-\mathrm{VC})$ & $\begin{array}{l}\text { Risks of } \\
\text { project } \\
\text { funding } \\
\text { from } \\
\text { different } \\
\text { sources; } \\
\text { the risk of } \\
\text { payback } \\
\text { of capital } \\
\text { invested }\end{array}$ \\
\hline $\begin{array}{l}\text { Financial } \\
\text { and } \\
\text { credit } \\
\text { organizat } \\
\text { ions }\end{array}$ & $\begin{array}{l}\text { 1. The volume of } \\
\text { mortgage loans in the } \\
\text { reporting year }\left(\mathrm{Q}_{\mathrm{r}}\right) \text { to the } \\
\text { volume of mortgage } \\
\text { loans in the base year } \\
(\mathrm{Q} \text { b), i.e, changing loan } \\
\text { conditions changes the } \\
\text { volume of loans (eg, an } \\
\text { upward change means } \\
\text { more loans issued), } \\
\text { rubles; } \\
2 . \text { The percentage of } \\
\text { returned and unreturned } \\
\text { loans }\left(\mathrm{K}_{\mathrm{r}, \text { ur. }}\right) \text { to the total }\end{array}$ & 更 & $\begin{array}{l}\text { The risk } \\
\text { of } \\
\text { changes in } \\
\text { financial } \\
\text { and loan } \\
\text { conditions } \\
\text { for } \\
\text { investmen } \\
t\end{array}$ \\
\hline
\end{tabular}

\begin{tabular}{|c|c|c|c|}
\hline & volume of loans $(\mathrm{Q}), \%$ & & \\
\hline $\begin{array}{l}\text { Govern } \\
\text { ment and } \\
\text { regulator } \\
\text { y } \\
\text { authoriti } \\
\text { es }\end{array}$ & $\begin{array}{l}\text { Percentage change in the } \\
\text { regulatory framework } \\
\left(\mathrm{LF}_{\mathrm{d}}\right) \text { to the total volume } \\
\text { of the entire legal and } \\
\text { regulatory framework } \\
\left(\mathrm{LF}_{\mathrm{t} .}\right) \text { share (for } \\
\text { example, } 40 \%) \text { changes } \\
\text { in legislation, \%. }\end{array}$ & $\mathrm{K}=\mathrm{LF}_{\mathrm{d}} / \mathrm{LF}_{\mathrm{t}}$ & $\begin{array}{l}\text { The risk } \\
\text { of } \\
\text { changes in } \\
\text { legal } \\
\text { regulation }\end{array}$ \\
\hline $\begin{array}{l}\text { Environ } \\
\text { mental } \\
\text { control } \\
\text { and } \\
\text { supervisi } \\
\text { on } \\
\text { authoriti } \\
\text { es }\end{array}$ & $\begin{array}{l}\text { Quantitative assessment } \\
\text { of the economic damage } \\
\mathrm{R}_{\mathrm{e}} \text {, the ratio of the } \\
\text { environmental risk to the } \\
\text { resulting damage due to } \\
\text { the implementation of } \\
\text { investment and } \\
\text { construction project, } \\
\text { rubles. The } \mathrm{R}_{\mathrm{e}} \text { - value of } \\
\text { environmental risk (eg, } \\
\text { year - 1); } \mathrm{Y} \text { - the value } \\
\text { of the resulting damage. }\end{array}$ & $R_{e}=R \times Y$ & $\begin{array}{l}\text { Environm } \\
\text { ental, } \\
\text { technologi } \\
\text { cal risks }\end{array}$ \\
\hline $\begin{array}{l}\text { Regional } \\
\text { mor- } \\
\text { tgage } \\
\text { agencies }\end{array}$ & $\begin{array}{l}\text { 1. The volume of } \\
\text { mortgage loans in the } \\
\text { reporting year }\left(\mathrm{Q}_{\mathrm{r}}\right) \text { to the } \\
\text { volume of mortgage } \\
\text { loans in the base year } \\
\left(\mathrm{Q}_{\mathrm{b}}\right) \text {, i.e, changing loan } \\
\text { conditions changes the } \\
\text { volume of loans (eg, an } \\
\text { upward change means } \\
\text { more loans issued), } \\
\text { rubles; } \\
2 . \quad \text { The difference } \\
\text { between the rate on loans } \\
\text { in the base period }\left(\mathrm{C}_{\mathrm{b}}\right) \\
\text { and the reporting period } \\
\left(\mathrm{C}_{\mathrm{r}}\right), \% \text {. }\end{array}$ & 1. $\mathrm{Q}=\mathrm{Q}_{\mathrm{r}} / \mathrm{Q}_{\mathrm{b}}$ & $\begin{array}{l}\text { The risk } \\
\text { of } \\
\text { changes in } \\
\text { financial } \\
\text { and loan } \\
\text { conditions } \\
\text { for } \\
\text { investmen } \\
\mathrm{t}\end{array}$ \\
\hline $\begin{array}{l}\text { Social } \\
\text { security } \\
\text { authori- } \\
\text { ties }\end{array}$ & $\begin{array}{l}\text { Total expenses }(C) \text { in the } \\
\text { consolidated budget of } \\
\text { the region under budget } \\
\text { item preferential } \\
\text { subsidies }\left(Q_{s}\right) \text { to total } \\
\text { expenditures }\left(Q_{t}\right) \text {, rubles. }\end{array}$ & $\mathrm{C}=\mathrm{Q}_{\mathrm{s}} / \mathrm{Q}_{\mathrm{t}}$ & $\begin{array}{l}\text { The risk } \\
\text { of } \\
\text { changes in } \\
\text { the } \\
\text { political } \\
\text { situation } \\
\text { (in terms } \\
\text { of social } \\
\text { policy) }\end{array}$ \\
\hline $\begin{array}{l}\text { Populati } \\
\text { on }\end{array}$ & $\begin{array}{l}\text { The ratio of per square } \\
\text { meter cost of low-rise } \\
\text { housing put into } \\
\text { operation in the } \\
\text { reporting year (Cr.) to } \\
\text { the base year (Cb.), } \\
\text { rubles. }\end{array}$ & $\mathrm{C}=\mathrm{Cr} / \mathrm{Cb}$ & $\begin{array}{l}\text { The risk } \\
\text { of } \\
\text { changes in } \\
\text { the cost of } \\
\text { constructi } \\
\text { on; }\end{array}$ \\
\hline $\begin{array}{l}\text { Public } \\
\text { control }\end{array}$ & $\begin{array}{l}\text { 1. The number of } \\
\text { violations of building } \\
\text { relations }(\mathrm{N}), \text { items. } \mathrm{Q}_{\mathrm{H}}- \\
\text { the number of violations; } \\
\mathrm{S}-\text { sq.m.of low-rise } \\
\text { housing; } \\
\text { 2. The number of public } \\
\text { complaints on the quality } \\
\text { of construction (Q), } \\
\text { items. } \mathrm{Q}_{S}-\text { - the number } \\
\text { of complaints satisfied; } \\
\mathrm{Q}_{\text {un - the number of }} \\
\text { complaints unsatisfied; P } \\
\text { - population. }\end{array}$ & 2. $\mathrm{Q}=\left(\mathrm{Q}_{s}+\mathrm{Q}_{u n}\right) / \mathrm{P}$ & $\begin{array}{l}\text { The risk } \\
\text { of } \\
\text { changes in } \\
\text { administra } \\
\text { tive } \\
\text { structure } \\
\text { of the } \\
\text { region }\end{array}$ \\
\hline
\end{tabular}


Each of these indicators indicates the probability of occurrence of risk events $[15,16,17]$, the development program of risk management, as well as the detailed study of required thresholds of suggested indicators for each investment and construction of low-rise housing project individually.

\section{TABLE II. INDICATORS OF INTERACTION EFFECTIVENESS OF HOUSING CONSTRUCTION, INDUSTRIAL CONSTRUCTION COMPANIES AND EDUCATIONAL ORGANIZATIONS IN LRC}

\begin{tabular}{|c|c|c|c|}
\hline $\begin{array}{c}\text { Indicat } \\
\text { or of } \\
\text { actor } \\
\text { efficien } \\
\text { cy in } \\
\text { LRC } \\
\text { project }\end{array}$ & Indicator description & $\begin{array}{l}\text { Indicator } \\
\text { calculation }\end{array}$ & $\begin{array}{l}\text { Type of } \\
\text { risk } \\
\text { correspo } \\
\text { nding to } \\
\text { the actors } \\
\text { functions }\end{array}$ \\
\hline $\begin{array}{l}\text { Compani } \\
\text { es of } \\
\text { investme } \\
\text { nt and } \\
\text { construct } \\
\text { ion } \\
\text { comp- } \\
\text { lex }\end{array}$ & $\begin{array}{l}\text { The ratio of profit derived } \\
\text { from the investment and } \\
\text { construction project }(\pi) \text { to } \\
\text { revenue }(\mathrm{R}), \% \text {. }\end{array}$ & $\mathrm{P}=(\pi / \mathrm{R}) \times 100 \%$ & $\begin{array}{l}\text { Business } \\
\text { planning } \\
\text { risks; }\end{array}$ \\
\hline $\begin{array}{l}\text { Research } \\
\text { organizat } \\
\text { ions }\end{array}$ & $\begin{array}{l}\text { The ratio of incomplete } \\
\mathrm{R} \& \mathrm{D}(\mathrm{H}) \text { to the total } \\
\text { number of projects in the } \\
\text { research organization } \\
\left(\mathrm{N}_{\mathrm{t}}\right), \% \text {. }\end{array}$ & $\mathrm{K}=\left(\mathrm{H} / \mathrm{N}_{\mathrm{t} .}\right) / \times 100 \%$ & $\begin{array}{l}\text { Innovatio } \\
\text { n risks }\end{array}$ \\
\hline $\begin{array}{l}\text { Architect } \\
\text { ural } \\
\text { design, } \\
\text { design } \\
\text { and } \\
\text { survey } \\
\text { organizat } \\
\text { ions }\end{array}$ & $\begin{array}{l}\text { The fact of passing the } \\
\text { design expertise, yes/no. }\end{array}$ & & $\begin{array}{l}\text { Project } \\
\text { planning } \\
\text { risks }\end{array}$ \\
\hline $\begin{array}{l}\text { Organiza } \\
\text { tions for } \\
\text { landscap } \\
\text { ing and } \\
\text { garde- } \\
\text { ning }\end{array}$ & $\begin{array}{l}\text { Deviation from the } \\
\text { normal average daily } \\
\text { temperatures, } \mathrm{t}^{\circ} \text {. }\end{array}$ & & $\begin{array}{l}\text { Climate } \\
\text { risks }\end{array}$ \\
\hline $\begin{array}{l}\text { Organiza } \\
\text { tions for } \\
\text { the } \\
\text { operatio } \\
\mathrm{n} \text { and } \\
\text { maintena } \\
\text { nce of } \\
\text { construct } \\
\text { ion } \\
\text { machiner } \\
y\end{array}$ & $\begin{array}{l}\text { Level intra-shift use of } \\
\text { equipment characterizes } \\
\text { the load factor } \mathrm{K} \text {, which } \\
\text { allows to estimate the } \\
\text { loss of time of the } \\
\text { equipment due to } \\
\text { scheduled preventive } \\
\text { maintenance, etc., hour. } \\
\mathrm{T}_{\mathrm{k}}-\mathrm{calendar} \text { fund of } \\
\text { time; } \mathrm{T}_{\mathrm{m}} \text { - modal time } \\
\text { fund; } \mathrm{T}_{\mathrm{eff}} \text { - effective-time } \\
\text { fund; } \mathrm{T}_{\mathrm{f}} \text { - real-time fund. }\end{array}$ & $\begin{array}{c}\mathrm{K}=\mathrm{T}_{\mathrm{f}} / \mathrm{T}_{\mathrm{k}} \text { or } \\
\mathrm{T}_{\mathrm{f}} / \mathrm{T}_{\mathrm{m}} \text { or } \mathrm{T}_{\mathrm{f}} / \\
\mathrm{T}_{\text {eff }}\end{array}$ & $\begin{array}{l}\text { The risks } \\
\text { of } \\
\text { deviation } \\
\text { from the } \\
\text { schedule } \\
\text { of works }\end{array}$ \\
\hline $\begin{array}{l}\text { Road } \\
\text { construct } \\
\text { ion } \\
\text { organizat } \\
\text { ions }\end{array}$ & $\begin{array}{lr}\text { Is } & \text { determined } \\
\text { individually for each } \\
\text { investment } \\
\text { construction project of } \\
\text { low-rise construction }\end{array}$ & & $\begin{array}{l}\text { Natural } \\
\text { and } \\
\text { geographi } \\
\text { cal risks }\end{array}$ \\
\hline $\begin{array}{l}\text { Energy } \\
\text { service } \\
\text { compani } \\
\text { es }\end{array}$ & $\begin{array}{l}\text { The coefficient of } \\
\text { energy saving in low- } \\
\text { rise building is } \\
\text { calculated as the ratio of }\end{array}$ & $\mathrm{K}=\left(\mathrm{C}_{\text {after }} / \mathrm{C}_{\text {before }}\right)$ & $\begin{array}{l}\text { Innovatio } \\
\text { n risks }\end{array}$ \\
\hline
\end{tabular}

\begin{tabular}{|c|c|c|c|}
\hline & $\begin{array}{l}\text { the cost of housing and } \\
\text { communal services after } \\
\text { energy service }\left(\mathrm{C}_{\text {after. }}\right) \text { to } \\
\text { the cost for housing and } \\
\text { communal services prior } \\
\text { to energy service } \\
\left(\mathrm{C}_{\text {before }}\right), \% \text {. }\end{array}$ & & \\
\hline $\begin{array}{l}\text { Organiza } \\
\text { tions } \\
\text { producin } \\
\mathrm{g} \\
\text { building } \\
\text { construct } \\
\text { ions and } \\
\text { materials }\end{array}$ & $\begin{array}{l}\text { The ratio of the } \\
\text { estimated cost of low- } \\
\text { rise construction in the } \\
\text { reporting period, to the } \\
\text { planning period, rubles. }\end{array}$ & $\mathrm{C}=\mathrm{Cr} / \mathrm{Cplan}$ & $\begin{array}{l}\text { The risk } \\
\text { of } \\
\text { changes in } \\
\text { the cost of } \\
\text { constructi } \\
\text { on }\end{array}$ \\
\hline $\begin{array}{l}\text { Engineer } \\
\text { ing and } \\
\text { utilities } \\
\text { organizat } \\
\text { ions }\end{array}$ & $\begin{array}{l}\text { The ratio of accidents in } \\
\text { engineering and utility } \\
\text { networks (A) to the total } \\
\text { volume of engineering } \\
\text { and utility networks } \\
\left(Q_{\text {t. }}\right), \% \text {. }\end{array}$ & $\mathrm{K}=\left(\mathrm{A} / \mathrm{Q}_{\mathrm{t} .}\right) \times 100 \%$ & $\begin{array}{l}\text { Technical } \\
\text { and } \\
\text { technologi } \\
\text { cal risks }\end{array}$ \\
\hline $\begin{array}{l}\text { Educati } \\
\text { onal } \\
\text { organiz } \\
\text { ations } \\
\text { (higher } \\
\text { and } \\
\text { seconda } \\
\text { ry } \\
\text { special } \\
\text { educatio } \\
\text { nal } \\
\text { instituti } \\
\text { ons) }\end{array}$ & $\begin{array}{l}\text { Graduate employment } \\
\text { rate }(\mathrm{E}) \text { characterized by } \\
\text { the ratio of employed } \\
\text { graduates to the total } \\
\text { number of graduates, } \\
\text { people. } \mathrm{N}_{\mathrm{e}} \text { - the number } \\
\text { of employed graduates, } \\
\text { people; } \mathrm{N}_{\mathrm{g}} \text { - the number } \\
\text { of graduates, people. }\end{array}$ & $\mathrm{E}=\mathrm{N}_{\mathrm{e}} / \mathrm{N}_{\mathrm{g}}$ & $\begin{array}{l}\text { The risk } \\
\text { of } \\
\text { changes in } \\
\text { staff } \\
\text { potential }\end{array}$ \\
\hline
\end{tabular}

\section{IV.CONCLUSION}

The study formed the organizational model for the implementation of the investment project of low-rise housing construction. Under the proposed model, we developed a system of indicators reflecting the efficiency of interaction between the actors of the investment project of low-rise housing construction. This model allows to define and systematize the interaction between the actors of the investment project, where for each actor, identified by the authors, functional efficiency and the associated risks arising in the implementation of LRC project are defined that will allow an objective assessment of the effectiveness of the LRC investment project implementation.

\section{REFERENCES}

[1] V.S. Kazejkin, S.A. Baronin, A.G. Chernyx, A.G. and A.N. Androsov, Problemnye aspekty razvitiya maloetazhnogo zhilishhnogo stroitelstva Rossii: monografiya, edited by V.S. Kazejkin and S.A. Baronin. M: Infra-M, 2011, 278 p.

[2] S.A. Baronin and P.G. Grabovyj, "Glavnye tendencii i sovremennye osobennosti razvitiya maloetazhnogo zhilishhnogo stroitelstva v Rossii", Izvestiya Yugo-zapadnogo gosudarstvennogo universiteta, 2011, № 5-2 (38), pp. 48a-58.

[3] A.N. Asaul, Y.N. Kazakov, N.I. Pasyada and I.V. Denisova, Teoriya i praktika maloetazhnogo zhilishhnogo stroitelstva v Rossii, edited by prof. A.N. Asaul, Saint Petersburg.: Gumanistika, 2005, 563 p.

[4] E.Yu. Bondarenko and L.V. Ivanenko, "Zarubezhnyj opyt organizacii maloetazhnogo stroitelstva", Osnovy ekonomiki, upravleniya i prava, 2013, vol. № 2 (8). 
[5] L. O'Toole, The "Implications for Democracy in a Networked Bureaucratic World", Journal of Public Administration Research and Theory, 1997, vol.7.

[6] R. Rhodes and D. Marsh, Policy Network in British Politics. A Critique of Existing Approaches, Policy Network in British Government. Oxford, 1992.

[7] World Bank Group Private Sector Development Strategy Implementation Progress Report, Washington, D.C., 2003.

[8] European Commission, Guidelines for Successful Public-Private Partnerships, 2003.

[9] 2007 Global Project Finance Yearbook, 2007, Standard \& Poor's. McGraw-Hill.

[10] J. Macsai, Housing, JohnWiley\&Sons, NewYork, 1976.

[11] T.N. Tanaeva, T.V. Uchinina and N.V. Usanova, "Obespechenie zhiloj zastrojki socialnoj infrastrukturoj pri organizovannom maloetazhnom stroitelstve”, Sovremennye problemy nauki i obrazovaniya, 2014, № 6 , p. 470.

[12] E.K. Ivakin and S.P. Belevcov, "Maloetazhnoe stroitelstvo: development i logistika”, Inzhenernyj vestnik Dona, 2011, № 4, vol. 18.

[13] S.G. Sheina and E.N. Minenko, Razrabotka optimizacionnoj modeli vybora energoeffektivnyx reshenij v maloetazhnom stroitelstve, Rostovon-Don, 2013, $118 \mathrm{p}$.

[14] M.L. Shpric, "Metody organizacii inveticionno-stroitelnoj deyatelnosti pri vozvedenii mnogofunkcionalnyx kompleksov", Izvestiya rossijskogo gosudarstvennogo pedagogicheskogo universiteta im. A.I. Gercena, 2013, № 163, p. 98-106.

[15] K.E. Filyushina and Yu.A. Kolyxaeva, "Novye podxody pri opredelenii i upravlenii riskami stroitelnogo kompleksa regiona $\mathrm{v}$ kontekste razvitiya gosudarstvenno-chastnogo partnerstva", Problemy sovremennoj ekonomiki, 2011, № 4, p. 473-478.

[16] E.G. Matugina, O.V. Pogharnitskaya, K.O. Petrova and A. B. Strelnikova, "Intensive use of energy resources regarding sustainable cities", IOP Conference Series: Earth and Environmental Science, 2015, Vol. 27, 4p.

[17] V. Konovalov, O. Pogharnitskaya, A. Rostovshchikova and I. Matveenko, "Potential of renewable and alternative energy sources", IOP Conference Series: Earth and Environmental Science, 2015, Vol. 27,5 p. 


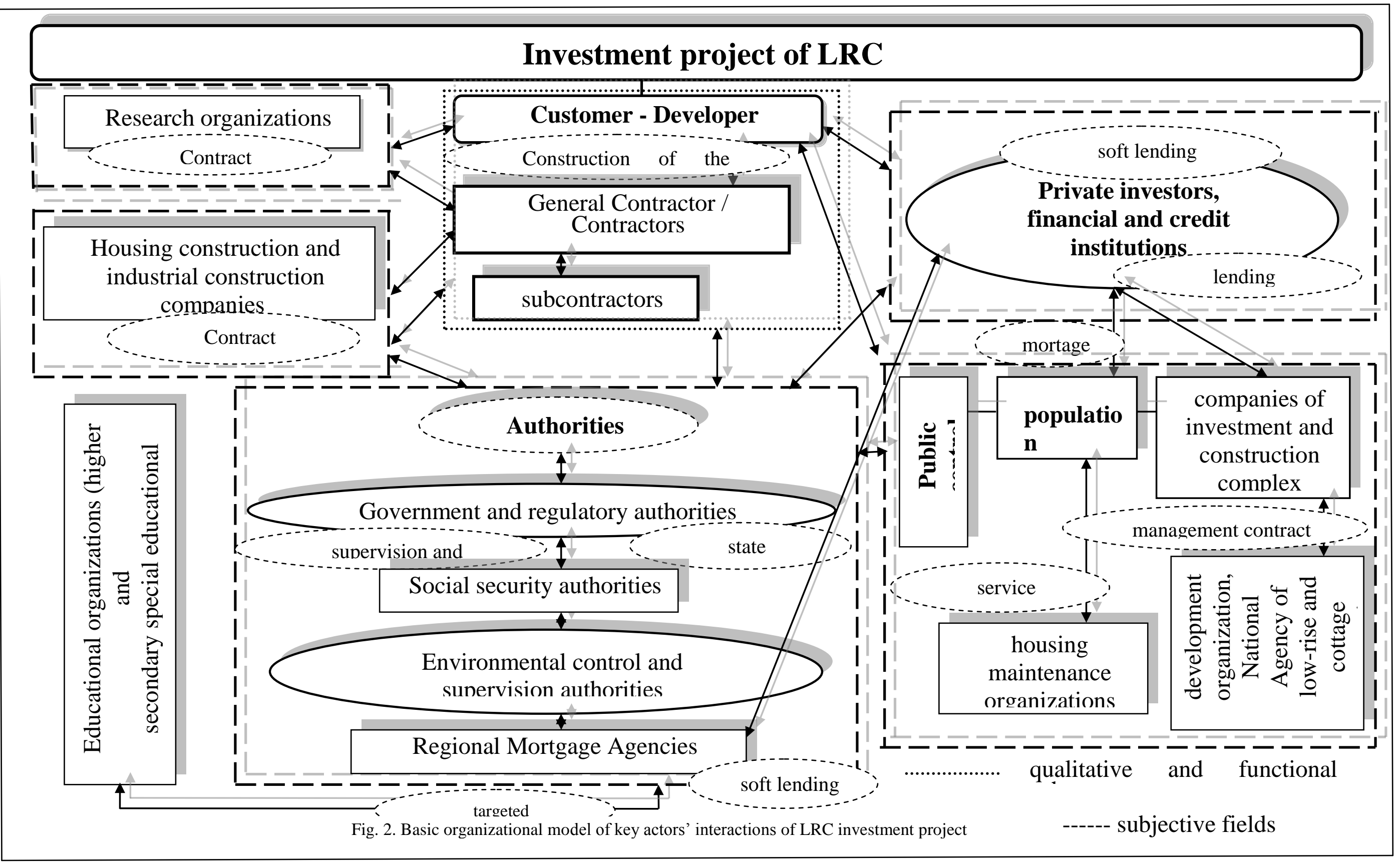


